O. Dubyna ${ }^{1,2}$, Dr. Sci. (Geol.), Senior Researcher, E-mail: dubyna_a@ukr.net;

S. Kryvdik², Dr. Sci. (Geol.-Min.), Prof., E-mail: kryvdik@ukr.net; V. Belskyy ${ }^{2}$, PhD (Geol.), E-mail: belskyi vm@ukr.net;

O. Vyshnevskyi ${ }^{2}$, PhD (Geol.-Min.), Senior Researcher, E-mail: vyshnevskyy@i.ua;

${ }^{1}$ Taras Shevchenko National University of Kyiv, Institute of Geology, 90 Vasylkivska Str., Kyiv, 03022, Ukraine; ${ }^{2}$ M.P. Semenenko Institute of Geochemistry, Mineralogy and Ore Formation of the NAS of Ukraine,

34 Acad. Palladina Ave., 03680, Kyiv-142, Ukraine

\title{
FEATURES OF BERILLIUM AND RARE METAL MINERALIZATION IN SYENITE OF THE PERGA DEPOSIT (UKRAINIAN SHIELD)
}

\begin{abstract}
(Представлено членом редакційної колегії д-ром геол.-мінералог. наук, проф. В.М. Загнітком)
The results of the ore and accessory minerals study in the syenite of the Perga beryllium deposit are discussed. Phenakite and genthelvite are found among Be-bearing minerals. Genthelvite of this syenite, being compared to early published data on genthelvite of the Perga deposit, is distinguished by the highest $\mathrm{ZnO}$ content which is close to the theoretical maximum) due to the alkaline nature of studied rock $((\mathrm{Na}+K) / \mathrm{Al}=1.09)$. Genthe/vite occurs as later mineral to phenakite or is formed by phenakite replacement at rising the alkalinity as a result of melt differentiation. Columbite with high-Mn content, Y-silicate (keiviite-(Y)?), rare-earth fluorocarbonate (bastnesite) are also found among other minerals of rare metals. The presence of fluorite and rare-earth fluorocarbonate in association with genthelvite or phenakite may indicate that Be and REE were transported in ore-bearing fluids as complex fluorine-carbonate compounds. Considering the geochemical characteristics of rocks (meta-aluminous, subalkaline and alkaline series, deep negative Euanomalies, low Sr, Ba, elevated-HFS elements) from the Sushcano-Perga region, enrichment of these rocks with rare metals and Be are related to intensive feldspar fractionation of the primary melts and due to alkaline oversaturation, volatile and rare metals $(B e, L i, R E E, Y$, $\mathrm{Nb}$, Ta) enrichment in the residual fractions of granitic or syenitic compositions. Postmagmatic alkaline solutions enriched in $\mathrm{F}$ and $\mathrm{CO}_{3}{ }^{2}$ promote of Be concentration in fluid phase with its following migration and crystallization as genthelvite.

Keywords: genthelvite, phenakite, subalkaline granites, alkaline syenites, columbite, Perga deposit, Ukrainian shield.
\end{abstract}

Problem statement. Minerals of the helvine series occur in rocks of different mineral composition and origin: helvine is more typical in skarns, granite - pegmatites, hydrothermal veins; danalite is mainly observed in skarns, (alkaline) granitiods and high-T metasomatites; genthelvite is associated with subalkaline and alkaline granites and syenitic rocks, alkaline pegmatites (Dunn, 1976).

The first publications about genthelvite find in siderophyllite greisen related to granites of the SushchanoPerga area (SPA) are dated to the 60s of the last century (Gurvich et al., 1963). Despite the occurrence of genthelvite mineralization in SPA is known for a long time, however, there are no reliable explanations of the origin of ore-bearing rocks as well as processes resulted in formation of such specific beryllium mineralization.

Recent publications review. There are different concepts about possible origin of genthelvite-bearing rocks in SPA. Gurvich S.I. with co-authors (Gurvich et al., 1963) has described these rocks as altered and enriched in quartz (silicificated syenites, which occur as small elongated or dike-like bodies in biotite granites. Based on the mineral composition - they include (\%): 50-70 perthitic microcline, 10-30 albite, 10-15 quartz, 3-5 biotite and 2-3 magnetite these rocks are interpreted to be microcline syenites similar to alkaline varieties. Superimposed hydrothermalpneumatolithic alterations resulted in formation of quartz veins and silicificated zones with associated genthelvite crystallization. Although the nature of such Be-enrichment of these fluids and Be concentration mainly in the genthelvite are still uncompletelly resolved problem.

In subsequent publications (Galetsky, 1966) the occurrence of genthelvite mineralization is mostly interpreted based on tectonic framework of the SPA that promote subalkaline granitoids formation and subsequent intensive auto- and metasomatic alterations with related rare metal mineralization. According to L.S. Galetskiy, Be mineralization itself should not be related to the specific syenitic (or granitic) rocks, but it occurs as confined to zones of intense metasomatic alteration formed in host granitoids by changing their composition to quartz-K-feldspar, quartz-albite-K-feldspar, quartz-K-feldspar-albite, mica-K-feldspar and quartzsiderophyllite metasomatites. Increased concentrations of $\mathrm{Ta}$, $\mathrm{Sn}, \mathrm{W}, \mathrm{Ag}, \mathrm{Li}, \mathrm{Rb}, \mathrm{Cs}, \mathrm{REE}, \mathrm{Y}, \mathrm{Fe}, \mathrm{Zn}, \mathrm{Mo}, \mathrm{Pb}$ in berylliumenriched rocks is interpreted to be a combined occurrence of two mineral associations: $\mathrm{Sn}-\mathrm{W}-\mathrm{Be}$ and polymetallic (Galetsky, 1966). According to this author, concentration of $\mathrm{Be}$ in genthelvite and formation of ore concentration of such unusual mineral association are treated to be a result of high enrichment of ore-bearing fluids in $\mathrm{S}, \mathrm{Si}$, as well as $\mathrm{Zn}$ and $\mathrm{Fe}$, and depletion in Al. Nevertheless, the nature of such specific solutions and mineral association as well as the relation between genthelvite and phenakite (described by L.S. Galetskiy for the first time) and possible sequence of their appearance still remain uncertain.

In later publications (Bezpal'ko, 1970) the genthelvitebearing rocks were called as "perthosites" and considered as metasomatic rocks (perthositic association), in spite of the fact that "perthosite" (according to petrographic code) is used for description of leucocratic variety of alkali feldspar syenite that consists almost entirely of perthite. Thus this term might be appropriate only in case of magmatic origin of these rocks. So other researchers termed these rocks as Kfeldspar metasomatites based on their metasomatic origin.

According to V.T. Shatska (Ginzburg et al., 1975) review that is based mainly on the results of V.M. Gorbunov, S.V. Metalidy, R.A. Slysh observations the ore sites are confined to the tectonic dislocation zones and adjacent fractures formed in quartz-feldspar granitoids (gneiss-like "granites"). Here granites are altered with formation of metasomatites of various compositions - quartz-biotitemicrocline to quartz-siderophyllite.

Article aims. The authors hope that petrographic and mineralogical studies of ore-bearing rocks of the Perga beryllium deposit will promote clearer understanding of the nature of ore mineralization and help to distinguish the peculiarities of the geological processes that resulted in $\mathrm{Be}-$ concentration as quite rare mineral species. 
Methods. Genthelvite was analyzed using a JCXA-733 (JEOL) electron microprobe, equipped with three vertical wavelength dispersive spectrometers, in the Institute of Geochemistry, Mineralogy and Ore Formation, NAS of Ukraine. Analytical conditions were as follows: beam acceleration voltage of $15 \mathrm{kV}$, beam current $20 \mathrm{nA}$, and beam diameter of $2 \mu \mathrm{m}$; counting times per analysis of $30 \mathrm{~s}$ on peak positions and $10 \mathrm{~s}$ on two background positions. Chemical composition of rare metal minerals was determined using a JSM-6700F field emission scanning electron microscope equipped with a JED-2300 energydispersive spectrometer (JEOL) in the Institute of Geochemistry, Mineralogy and Ore Formation, NAS of Ukraine. Operating conditions were as follows: $20 \mathrm{kV}$ accelerating voltage, $1,0 \mathrm{nA}$ beam current, $2 \mu \mathrm{m}$ beam size and a counting time of 90 seconds for one analysis. Pure metals, synthetic compounds and natural minerals were used for calibration. Raw counts were corrected for matrix effects with the ZAF algorithm implemented by JEOL.

Petrography. Set of samples collected from the waste dumps of the Perga mine is studied. Petrographic descriptions have shown the most interesting rock according to their mineralogy (almost completely consist of perthite and minor albite, lattice microcline and quartz (10-15\%)) and chemical composition $\left(\mathrm{SiO}_{2} 63,99, \mathrm{TiO}_{2} 0,11, \mathrm{Al}_{2} \mathrm{O}_{3}\right.$ $16,64, \mathrm{Fe}_{2} \mathrm{O}_{3}$ 1,07, $\mathrm{FeO} 1,86, \mathrm{MnO} 0,04, \mathrm{MgO} 0,38, \mathrm{CaO}$ $0,71, \mathrm{Na}_{2} \mathrm{O} 5,23, \mathrm{~K}_{2} \mathrm{O} 8,87, \mathrm{P}_{2} \mathrm{O}_{5}$ 0,04, Total 99.18) can be classified as quartz alkali-feldspar syenite. Geochemical investigation have shown the presence (in ppm): $5000 \mathrm{Ba}$, $200 \mathrm{Ba}, 250 \mathrm{~L}, 100 \mathrm{Nb}, 450 \mathrm{Zr}, 500$ Y, 60 La, $200 \mathrm{Ce}, 100$ Th. Large perthite grains which are found in the most samples are characterized by simple twinning that together with perthite have a "fir-like" shapes under crossed links (Carlsbad twinning), which are more typical for orthoclase. According to (Menert, 1971), such exsolution of primary KNa-feldspars can occur at solvus temperatures (660$715^{\circ} \mathrm{C}$ ), while crosshatched twinning of microcline formed as a result of rearrangement of earlier monoclinic orthoclase, at temperature not lower than $500^{\circ} \mathrm{C}$. Based on the results of homogenization of gas-liquid inclusions ore metasomatites (with genthelvite and willemite) are formed at $400-500^{\circ} \mathrm{C}$.

The amount of perthite intergrowths (30-50\%) in porphyry-like feldspar indicates high-temperature crystallization environment of this rock. It is widely known that at low temperature conditions albite and microcline that occur in hydrothermal rocks and low-temperature metasomatites are commonly crystallized as separate grains. Microcline grains with typical microcline twinning are smaller in size relative to grains of perthitic feldspar and can be found in crushing zones in association with fine grained quartz, that can indicate their formation at later stages. Besides rock-forming minerals and above mentioned genthelvite plus phenakite such ore and accessory minerals as columbite, monazite, rare earth carbonate, zircon, magnetite, tungstenite (series tungstenite-gubnerite), as well as undiagnosed $\mathrm{Y}$-silicate (keiviite-(Y)?) are found in this sample.

The studied rock is slightly oversaturated in alkalis and has increased agpaitic index $((\mathrm{Na}+\mathrm{K}) / \mathrm{Al}=1,09)$, although the alkali minerals have not been found. At the same time early publications (Ginzburg et al., 1975; Myckevych et al., 1986) have presented analytical data on peralkaline "feldspar metasomatites" $((\mathrm{Na}+\mathrm{K}) / \mathrm{Al}=0,98-1,10)$ found in SPA. Agpaitic nature of this rock might be a result of partial entering of $\mathrm{Fe}^{+3}$ into tetrahedral position of feldspar with associated decreasing in aluminum and resultant oversaturation in alkalis. Based on the obtained data the studied syenite might be considered as rock variety very similar to leucocratic syenites of the Yastrubetsky massif, which is also situated among granites of SPA. It should be noted that these syenites are also characterized by increased $\mathrm{Be}$ (up to $33 \mathrm{ppm}$ in syenites and only up to $20 \mathrm{ppm}$ in the Perga granites) (Dubyna et al., 2014), as well as by $\mathrm{Zr}, \mathrm{REE}, \mathrm{Nb}, \mathrm{Y}$. Data presented in this article taken together with results observations made by N.A. Bezpal'ko, make it possible to suppose that "perthosite" occurs as veins and might represent the dyke swarm or vein facies of the Yastrubetsky massif or syenites that are very similar to them.

Chemical composition of genthelvite. Earlier investigations carried out in SPA distinguished several generations of genthelvite from three (Ginzburg et al., 1975) to four (Galetsky, 1966) and up to seven (Metalydy and Nechaev, 1983). According to the early published data, genthelvite crystals commonly show zonal structure with various zones of different chemical composition (Tabl. 1). It is possible that these zones might be erroneously interpreted by early researchers as separate generations. In one of publication (Remeshilo et al., 1977) has discussed zonal crystal of genthelvite with up to 13 zones distinguished based on rather variable content of $\mathrm{Zn}$ and $\mathrm{Fe}$ (but without significant variations in $\mathrm{Mn}$. Accordingly to (Metalid and Nechaev, 1983), have made an assumption about higher Zn and lower $\mathrm{Fe}$ contents in late generations but without presenting any detailed analytical results. The highest content of $\mathrm{ZnO}(53,3 \%)$ was determined in the second generation of this mineral.

By early investigation genthelvite is crystallized in different rock varieties of SPA: syenites (perthosites), greisens and silicified varieties of these rocks. Among investigated samples leucocratic perthitic syenites characterized by the highest content of genthelvite. Our own results and their comparison with data of previous publication indicate that these varieties of genthelvite show maximum enrichment in zinc ( $\mathrm{ZnO}$ up to $55,6 \%$ ) (Fig. 1). Separate genthelvite generation is not possible to be distinguished however in some cores of zonal crystals higher $\mathrm{Zn}$ contents are fixed in comparison to their rims.

Chemical composition of genthelvite from syenites of the Perga deposit

\begin{tabular}{|l|c|c|c|c|c|c|c|c|c|c|c|c|c|c|c|c|}
\hline & 1 & 2 & 3 & 4 & 5 & 6 & 7 & 8 & 9 & 10 & 11 & 12 & 13 & 14 & 15 & 16 \\
\hline $\mathrm{SiO}_{2}$ & 28,94 & 29,68 & 29,49 & 28,98 & 30,98 & 31,00 & 31,06 & 31,13 & 31,03 & 31,01 & 30,95 & 30,62 & 30,67 & 30,96 & 31,02 & 31,02 \\
\hline $\mathrm{BeO}_{\text {calc }}$ & 12,74 & 12,66 & 12,45 & 12,43 & 12,89 & 12,90 & 12,92 & 12,95 & 12,91 & 12,90 & 12,88 & 12,74 & 12,76 & 12,88 & 12,91 & 12,91 \\
\hline $\mathrm{ZnO}$ & 55,64 & 52,29 & 52,18 & 53,02 & 53,37 & 52,84 & 45,46 & 45,54 & 45,17 & 51,79 & 49,31 & 51,93 & 52,61 & 51,94 & 50,27 & 48,25 \\
\hline $\mathrm{FeO}$ & 1,47 & 1,45 & 1,92 & 1,84 & 0,83 & 0,83 & 6,63 & 6,92 & 7,46 & 3,15 & 4,46 & 2,11 & 2,15 & 1,38 & 4,29 & 4,66 \\
\hline $\mathrm{MnO}$ & 0,23 & - & 0,25 & 0,03 & 1,43 & 1,93 & 2,72 & 2,46 & 2,11 & 0,56 & 1,33 & 0,84 & 0,29 & 2,11 & 0,78 & 2,17 \\
\hline $\mathrm{S}$ & 5,44 & 5,40 & 5,32 & 5,31 & 5,50 & 5,51 & 5,52 & 5,53 & 5,51 & 5,51 & 5,50 & 5,44 & 5,45 & 5,50 & 5,51 & 5,51 \\
\hline Total & 104,46 & 102,96 & 101,61 & 101,60 & 105,00 & 105,00 & 104,30 & 104,53 & 104,19 & 104,91 & 104,42 & 103,67 & 103,94 & 104,76 & 104,78 & 104,51 \\
\hline$-1 / 2 \mathrm{~S}$ & 101,74 & 100,26 & 98,95 & 98,95 & 102,25 & 102,24 & 101,55 & 101,77 & 101,44 & 102,16 & 101,68 & 100,95 & 101,21 & 102,01 & 102,02 & 101,76 \\
\hline
\end{tabular}




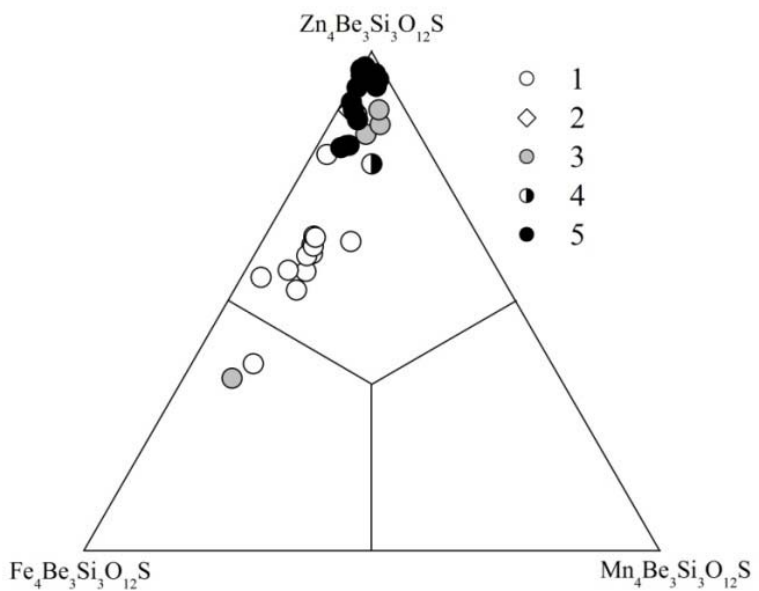

Fig. 1. Composition of genthelvite of the Perga deposit are plotted on triangle diagram of helvite-danalite-genthelvite coordinates. Legend:

1 - (Remeshilo et al., 1977); 2 - (Metalid, Nechaev, 1983);

3 - (Ginzburg et al.,1977); 4 - (Galetsky, 1966); 5 - author's data published in this paper (Tabl. 1)

In our opinion, another feature of the beryllium-bearing rocks of SPA, which is still obscure, concerns the interrelation between two beryllium minerals - genthelvite (abundant) and phenakite. Based on early publications about SPA it is widely known that phenakite is confined to the silicified zones of gneiss-like granites, greisens and syenites (Ginzburg et al., 1975, 1977).

According to these investigations phenakite commonly was found at the peripheral part of genthelvite enriched areas, and phenakite being crystallized later than genthelvite at lower temperature $\left(180-250^{\circ} \mathrm{C}\right)$ during of metasomatic stage. As one of main of mentioned arguments is presence of phenakite on the margin of genthelvite grains. However, it should be mentioned that association of phenakite and helvite series minerals is commonly observed in metaluminous or peralkaline rocks, so alkaline Besilicates is more typical for alkaline rocks unsaturated with silica. Phenakite is also observed (oral evidence from one of author of this paper) in Perga porphyry granite (biotite and oligoclase) i.e. without any presence of alkaline minerals.

The results of petrographic and mineralogical studies made on quartz-alkali-feldspar syenite do not prove early concept about crystallization sequence of beryllium minerals, or, at least, indicate the ambiguity of the supposed relation between genthelvite and phenakite. In addition, the above mentioned low-temperature conditions of phenakite crystallization disagree with experimental data on phenakite

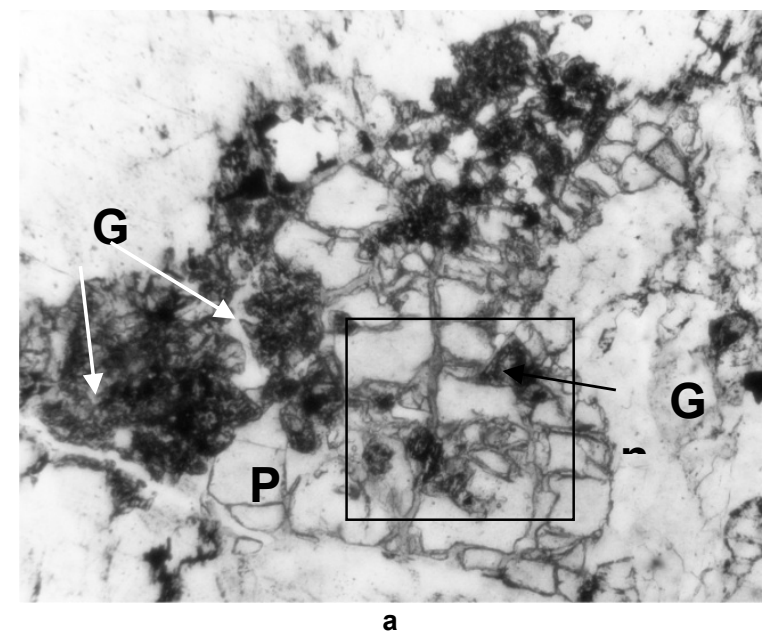

and bertrandite stability at moderate pressures $(0,5-$ $3,5 \mathrm{kbar}$ ) and temperatures (up to $\sim 350^{\circ} \mathrm{C}$ ) where bertrandite is more stable in comparison with phenakite (Hsu, 1983)

In the studied samples (thin and polished sections) single crystals of genthelvite and phenakite are commonly found. Phenakite is generally larger in size and shows presence of fissures filled with iron phase (hematite?) and rarely rare-earthfluorocarbonate. In thin sections, large phenakite crystals (Fig. 2) are common. Sometimes in cracks and on the edges of these crystals fine-grained $(<0.1 \mathrm{~mm})$ and tetrahedral (triangular in shape) crystals of genthelvite are developed. In addition, core parts of large triangular genthelvite crystals (by transparent light) are filled with brownish aggregate where small relics of phenakite are also discovered. Fine-grained $(<10 \mu \mathrm{m})$ genthelvite rim around smaller $(\sim 100 \mu \mathrm{m})$ phenakite crystals are found but they are more rare. It is possible to suppose that phenakite is earlier mineral, at least in the investigated syenite. At alkalinity increasing of granitoid melt or ore-bearing solutions phenakite became unstable and was replaced by genthelvite.

Other rare metal minerals. As mentioned above, granitoids and studied syenite sampled in the Perga mine are characterized by increased contents of LIL and HFS elements too. Among minerals that contain these elements columbite, ferropseudobrookite, monazite, bastnäsite and Y-silicate are studied (Tabl. 2).

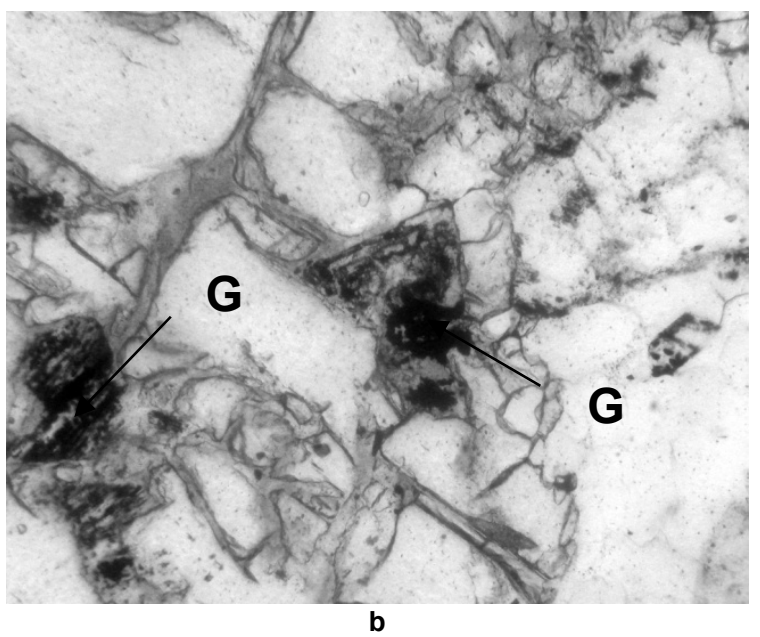

Fig. 2. a - the large $(\sim 3 \mathrm{~mm}$ ) grain of phenakite (Phe) with small (usually $<100 \mu \mathrm{m}$, commonly triange in shape) grains of genthelvite $(\mathrm{Gn})$ (magnification $40^{\times}$) in fractures; $b$ - genthelvite grains of (magnified part of A) image, magnification $100^{\star}$ ). Photos in transparent light 
Table 2

Chemical composition of rare metal minerals from syenites of the Perga deposit

\begin{tabular}{|c|c|c|c|c|c|c|c|c|c|c|c|c|c|c|c|c|}
\hline & 1 & 2 & 3 & 4 & 5 & 6 & 7 & $8^{*}$ & 9 & $10^{*}$ & \multirow{2}{*}{\begin{tabular}{|c|}
$11^{*}$ \\
IImenorutile
\end{tabular}} & \multirow{2}{*}{ Monazite } & 13 & 14 & $15^{*}$ & $16^{*}$ \\
\hline & \multicolumn{6}{|c|}{ Columbite } & \multicolumn{4}{|c|}{ Ferropseudobrookite } & & & \multicolumn{2}{|c|}{ Keiviite-(Y) } & \multicolumn{2}{|c|}{$\begin{array}{c}\text { REE-F- } \\
\text { carbonate }\end{array}$} \\
\hline $\mathrm{SiO}_{2}$ & 2,06 & 1,63 & 2,58 & & & & 2,12 & & & 3,22 & 4,17 & 1,69 & 40,98 & 39,12 & 2,49 & 0,34 \\
\hline $\mathrm{TiO}_{2}$ & 3,65 & 2,38 & 2,93 & 3,09 & 2,44 & 2,18 & 69,78 & 58,27 & 70,26 & 65,69 & 67,22 & & & & 0,13 & 0,01 \\
\hline $\mathrm{FeO}$ & 15,21 & 13,75 & 14,34 & 15,41 & 16,64 & 13,71 & 26,9 & 26,03 & 27,25 & 25,72 & 19,12 & & 2,34 & 3,05 & 18,1 & 1,34 \\
\hline $\mathrm{MnO}$ & 5,55 & 6,03 & \begin{tabular}{|l|}
5,88 \\
\end{tabular} & \begin{tabular}{|l|}
3,89 \\
\end{tabular} & 2,59 & 6,22 & 1,2 & 12,63 & 2,49 & \begin{tabular}{|l|}
1,04 \\
\end{tabular} & 0,2 & & & & 0,05 & 0,04 \\
\hline $\mathrm{CaO}$ & & & & & & & & & & & & & \begin{tabular}{|l|}
5,01 \\
\end{tabular} & 4,46 & 2,05 & 0,67 \\
\hline $\mathrm{F}$ & & & & & & & & & & & & & & & 2,67 & 11,02 \\
\hline $\mathrm{Nb}_{2} \mathrm{O}_{5}$ & 73,52 & 76,2 & 74,27 & 72,41 & 75,94 & 76,33 & & & & & 2,99 & & & & & \\
\hline $\mathrm{Ta}_{2} \mathrm{O}_{5}$ & & & & 5,21 & 2,39 & 1,56 & & & & & & & & & & \\
\hline $\mathrm{P}_{2} \mathrm{O}_{5}$ & & & & & & & & & & & & 29,75 & & & \begin{tabular}{|l|}
0,01 \\
\end{tabular} & \\
\hline $\mathrm{Y}_{2} \mathrm{O}_{3}$ & & & & & & & & & & & & & 51,67 & 53,38 & 14,13 & 1,45 \\
\hline $\mathrm{La}_{2} \mathrm{O}_{3}$ & & & & & & & & & & & & 16,06 & & & 4,14 & 19,65 \\
\hline $\mathrm{Ce}_{2} \mathrm{O}_{3}$ & & & & & & & & & & & & 39,59 & & & 8,54 & 28,8 \\
\hline $\mathrm{Nd}_{2} \mathrm{O}_{3}$ & & & & & & & & & & & & & & & 4,27 & \begin{tabular}{|c|}
9,35 \\
\end{tabular} \\
\hline $\mathrm{REE}_{2} \mathrm{O}_{3}{ }^{\text {tot }}$ & & & & & & & & & & & & & & & 32,41 & 62,11 \\
\hline $\mathrm{ThO}_{2}$ & & & & & & & & & & & & 12,92 & & & \begin{tabular}{|l|}
0,54 \\
\end{tabular} & 0,25 \\
\hline Total & 100 & 100 & 100 & 100 & 100 & 100 & 100 & 100 & 100 & 100 & 100 & 100 & 100 & 100 & 63,05 & 78,15 \\
\hline
\end{tabular}

${ }^{*}$ Following elements are also determinedin presented analysis are: $8-3,07 \mathrm{ZnO} ; 10-4,34 \mathrm{ZrO}_{2} ; 11-6,3 \mathrm{ZrO}_{2} ; 15-3,02 \mathrm{Al}_{2} \mathrm{O}_{3} ; 0,17$ $\mathrm{MgO} ; 0,66 \mathrm{SrO} ; 0,09 \mathrm{Na}_{2} \mathrm{O} ; 0,6 \mathrm{PbO}_{2} ; 0,05 \mathrm{UO}_{2} ; 0,91 \mathrm{Pr}_{2} \mathrm{O}_{3} ; 0,28 \mathrm{Eu}_{2} \mathrm{O}_{3} ; 0,14 \mathrm{Sm}_{2} \mathrm{O}_{3} ; 16$ - 0,89 $\mathrm{SrO} ; 2,77 \mathrm{Pr}_{2} \mathrm{O}_{3} ; 0,73 \mathrm{Eu}_{2} \mathrm{O}_{3} ; 0,61 \mathrm{Sm}_{2} \mathrm{O}_{3}$; $0,2 \mathrm{~Tb}_{2} \mathrm{O}_{3}$

1-3-analysis from different part of single grain; 4, 5- fine-grained (about $60 \mu \mathrm{m}$ ) irregularly shaped columbite; 6 - similar to previous neighboring grain; 7-10 - analysis from different part of single elongated (about $0.6 \mathrm{~mm}$ ) grain; 11 - single grain in association with columbite; 12 - core (unaltered) part of small (about $140 \mu \mathrm{m}$ ) elongated grain; 13, 14 - the most large (up to $15 \mu \mathrm{m}$ ) grain in fine-grained segregation around magnetite; 15 - small (up to $50 \mu \mathrm{m}$ ) inclusion in core part of genthelvite; 16 - single grain (up to $250 \mu \mathrm{m}$ ) next to zircon.

Columbite occurs as small $(0,1 \mathrm{~mm})$ crystals of irregular shape with corroded faces. Locally at grain edges a thin rim of secondary ferruginous phase (hematite?) is formed, though some intergrowths between columbite, isometric magnetite (?) and ilmenorutile are also found. The contents and ratio of main components are consistent with columbite analyses that were published earlier (Buchinskaya and Nechaev, 1992) and point out to increased of Mn content. The similar Mn-rich columbites are described by these authors in the aegirine-biotite and siderophyllite granites of SPA.

Ferropseudobrookite forms elongated $(0.6 \times 0.15 \mathrm{~mm})$ crystal which sometimes shows presence of idiomorphic faces. On back-scattered electron image, crystal looks like homogeneous grains, with one single point showing significant increase of $\mathrm{MnO}$ and $\mathrm{ZnO}$ (Tabl. 2, an. 8).

Keiviite-(Y) (?) is a secondary mineral which is most commonly observed in cracks of quartz and fluorite from "amazonite" pegmatite's. The minerals that might be preliminarily diagnosed (by the ratios of main elements $(\mathrm{Y}: \mathrm{Si}$ $=1: 1)$ ) as keiviite- $(Y)$ occur only as fine aggregates $(<5 \mu \mathrm{m})$ that surround large magnetite grain. These aggregates include larger grains (up to $15 \mu \mathrm{m}$ ) of irregular shape, among which one single grain was analyzed. But more detailed investigation is needed, because in analyzed grain only $Y$ is presented, whereas typical keiviite- $(Y)$ should also be enriched in HREE.

Bastnäsit might be found as small inclusions in genthelvite, in cracks of phenakite and single small grains. The presence of rare-earth-fluorocarbonate and obvious secondary (or late) nature of their occurrence as confined to beryllium minerals as well as constant presence of fluorite prove the conclusions of experimental studies. These results testify that the main agents of postmagmatic or hydrothermal fluids, which are responsible for the transfer and concentration of $\mathrm{Be}$, are not purely fluorine but $\mathrm{F}-\mathrm{CO}_{3}{ }^{2-}$ is in composition that is more typical for alkaline conditions.

Conclusions. It is known that subalkaline and peralkaline magmas can concentrate Be in different rocks ranging in composition from subalkaline biotite granites and syenites to riebeckite-aegirine varieties. As a rule, magmatic rocks similar to alkaline granites and quartz syenites show rather high Be contents (Khaldzan-Buregtey, Mongolia), although ore mineralization are mainly associated with alkaline pegmatites (Strange Lake, Thor Lake, Canada) formed at the final stages of granitoid melts differentiation.

According to published data (Esypchuk et al., 1993; Dubyna and Kryvdik, 2014), chondrite-normalized REE patterns of the Perga granites and syenites of the Yastrubetsky massif are characterized by large negative Euanomalies $\left(\mathrm{Eu} / \mathrm{Eu}^{*}=0,05-0,11\right)$ and significant enrichment in HREE $\left((\mathrm{La} / \mathrm{Yb})_{\mathrm{n}}=0,3-20\right)$. Such REE distribution patterns and other geochemical features (low $\mathrm{Sr}$ and $\mathrm{Ba}$, high HFSE) give us a reason to assert that at least the alkaline varieties of the Perga granites and associated syenites, i.e. syenites of the Yastrubetsky massif, are formed as a result of intensive crystalline fractionation of granitic or syenitic melts. Apparently, these processes of differentiation could be responsible for formation of residual melts enriched in volatile and alkaline elements with associated increasing of fluorine and rare metal $(\mathrm{Be}, \mathrm{Li}, \mathrm{REE}, \mathrm{Y}, \mathrm{Nb}, \mathrm{Ta})$ contens.

Therefore, the main reason of increased concentration of $\mathrm{Be}$ in SPA is likely to be explained by geochemical characteristics of highly differentiated melts, namely, reduced in aluminum content (metaluminous) and increased alkalinity. It can be also proved by the fact of enrichment in Be and rising of $\mathrm{Zr}$, Nb, REE concentrations, which is typical for the similar types of alkaline or subalkaline magmas. In addition, low or reduced aluminum content and high alkalinity can promote formation of phenakite instead of beryl that is more typical for peraluminous granites. At entering of these melts into hypabyssal environment and their subsequent crystallization, volatile enriched solutions could be separated, that adduce to increasing of $\mathrm{Be}$ solubility and its accumulation in the fluid phase. Low activity of $\mathrm{SiO}_{2}$ in the syenite rocks could also enhance this effect. The presence of fluids enriched in $\mathrm{Be}$ and other rare metals, that are genetically associated with subalkaline or alkaline granites and syenites, high oxygen fugacity and low sulfur content, are favorable for transportation and subsequent concentration of $\mathrm{Be}$ in genthelvite. Genthelvite can be crystallized together with phenakite or by its replacement. At the same time, genthelvite of alkaline syenites is characterized by the $\mathrm{ZnO}$ content that is very similar to the 
theoretically calculated composition, which is related with alkaline conditions of this mineral crystallization.

In our opinion, significant $\mathrm{Zn}$ enrichment of genthelvite found in studied sample is caused by its elevated alkalinity. As is known, genthelvite is the member of sodalite-danalite series, which is characterized by entering of $\mathrm{S}\left(\right.$ or $\left.\mathrm{SO}_{4}^{-2}\right)$ in additional anions, that is caused, on the one hand, by reduced sulfur and elevated oxygen fugacity, and on the other hand, by increased alkalinity of the melt where Fe and Mn comprise oxides and other silicates (Burt, 1988). Therefore, at crystallization of alkaline melts occurrence of hydrothermal and sulfide mineralization is not typical, and $\mathrm{S}$, $\mathrm{SO}_{4}{ }^{-2}$ and $\mathrm{H}_{2} \mathrm{O}$, together with $\mathrm{Na}$, enter into silicate minerals (sodalite, cancrinite, haüyne, nosean).

Experimentally studied relation between $\mathrm{FeO}$ and $\mathrm{ZnO}$ solubility and $\mathrm{pH}$ of solution is also indicates that in range of $\mathrm{pH}$ from 9 to 11, their solubility is practically the same. At these condition $\mathrm{Be}$ and $\mathrm{Zn}$ migrate as similar complexes: $\mathrm{Be}(\mathrm{OH})_{2}$ and $\mathrm{Zn}(\mathrm{OH})_{2}, \mathrm{Be}(\mathrm{OH})^{-3}$ and $\mathrm{Zn}(\mathrm{OH})^{-3}$, which determines their occurrence in the same minerals (Khodakovsky, 1975). In addition, the geochemical feature of $\mathrm{Be}$ is formation of stable complexes with fluorine $\left(\left[\mathrm{BeF}_{4}\right]^{2-}\right.$, $\left.\left[\mathrm{BeF}_{3}\right]^{2-},\left[\mathrm{BeF}_{2}\right],[\mathrm{BeF}]^{+}\right)$, which prevail at low $\mathrm{pH}(2-5)$, while mixed $\mathrm{F}-\mathrm{CO}_{3}{ }^{2-}$ complexes (such as $\mathrm{BeCO}_{3} \mathrm{~F}^{-}$) are predominant at higher $\mathrm{pH}$ (5-7) (Wood, 1992). According to experimental data (Kogarko et al., 1968), the fluorine separation in the fluid phase rise with increased acidity of the silicate melt and sharply decreases with increasing alkalinity. Therefore, in agpaitic melts, $\mathrm{F}$ is not separated into gas phase at all, subsequently silicate melt gradually passes into the fluid-melt from which pegmatites with various minerals (including soluble in water $\mathrm{NaF}$, sodium phosphates, soda and another rare earth minerals) are crystallized. These pegmatites might be treated to certain extent as similar to coarse-grained "perthosite".

Such crystallization enriched in $\mathrm{Zn}$ (and $\mathrm{Mn}$ ) minerals might be found in highly differentiated (residual) melts represented by alkaline rocks. For example, Zn-kupletskite (up to 7,86 \% $\mathrm{ZnO}$ ) and hendricksite (21,5-25,8 \% $\mathrm{ZnO}$ ) were discovered in agpaitic phonolites of the Oktyabrsky massif (Azov area), and high-Mn (up to 8,7 \% $\mathrm{MnO}$ ) amphibole and biotite (up to $3,52 \mathrm{ZnO}$ and up to $14,3 \% \mathrm{MnO}$ ) are also known in dike aegirine microphoyaites of this massif.

Possible influence of hydrothermal processes on the ore-ability of Be deposits that are associated with granite intrusions is still controversial, because sometimes both primary magmatic (Miller, 1996) and hydrothermal enrichments (Salvi and Williams-Jones, 1996) are treated to be important even for the same deposits. The reviews of published data show in spite of high Be content in pegmatoid alkaline rocks, the highest $\mathrm{Be}$ concentrations are still associated with later hydrothermal processes. Based on the type of mineralization of the beryllium-bearing rocks of SPA they are quite similar to fluorite-phenakite-helvite mineralization of the Verhnee Espe district (Kazakhstan), which occurs at the marginal zones of hydrothermally altered porphyry alkaline (riebeckite) granites.

\section{Список використаних джерел}

Безпалько, Н.А. (1970). Петрологія і акцесорні мінерали гранітів та метасоматитів Північної Волині. Київ: Наукова думка.

Бучинская, К.М., Нечаев, С.В.(1994). Тантал-ниобиевая минерализация Пержанского рудного узла (Украинский щит). Минералогический журнал, 1, 15-29.

Галецкий, Л.С. (1966). О необычном парагенезисе гентельвина и касситерита. Минералогический сборник Львовского у-та, 20, 46-52.

Гинзбург, А.И., Заболотная, Н.П., Куприянова, И.И., Новикова, М.И., Шацкая, В.Т., Шпанов, Е.П., Шурига, Т.Н., Гетманская, Т.И. (1975). Генетические типы гидротермальных месторождений бериллия. Москва: Недра.

Гинзбург, А.И., Заболотная, Н.П., Куприянова, И.И., Новикова, М.И., Шацкая, В.Т., Шпанов, Е.П. (1977). Закономерности формирования гидротермальных месторождений бериллия. Москва: Недра.
Гурвич, С.И., Зубко, Л.Б., Галецкий, Л.С. (1963). Генгельвин из окварцованных сиенитов. Докпады АН СССР, 5, 1123-1124.

Дубина, О.В., Кривдік, С.Г. (2014). Геохімічні та петрологічні особливості лужних гранітоїдів Українського щита Геологічний журнал, 3, 83-94. Есипчук, К.Е., Орса, В.И., Щербаков, И.Б. и др. (1993). Гранитоиды Украинского щита. Петрохимия, геохимия, рудоносность. Киев: Наукова думка.

Когарко, Л.Н. (1977). Проблема генезиса агпаитовых магм. Москва: Наука.

Менерт, К.Р. (1971). Мигматиты и происхождение гранитов. Москва: Мир.

Металиди, С.В., Нечаев, С.В. (1983). Сущано-Пержанская зона (геология, минералогия, рудоносность). Киев: Наукова думка.

Мицкевич, Б.Ф., Безпалько, Н.А., Егоров, О.С. и др. (1986). Редкие элементы Украинского щита. Киев: Наукова думка.

Ремешило, Б.Г., Вынар, О.Н., Дручок, Л.П., Самойлович, Л.Г., Слыш, Р.А. (1977). К условиям формирования зональных кристалов гентгельвина. Тезисы докл. респ. симпоз. "Минералогические критерии поисков редких металлов в пределах Украинского щита". Киев: Наукова думка.

Ходаковский, И.Л. (1975). Исследования в области термодинамики водных растворов при высоких температурах и давлениях. Авторефр. дис... д-ра геол. наук. Москва.

Шарыгин, В.В., Кривдик, С.Г., Поспелова, Л.Н., Дубина, А.В. (2009). Znкуплетскит и хендриксит в агпаитовых фонолитах Октябрьского массива, Приазовье, Украина. Докл. АН РАН, 6, 810-815

Barton, M.D., Young, S. (2002). Non-pegmatitic Deposits of Beryllium: Mineralogy, Geology, Phase Equilibria and Origin. In Beryllium: Mineralogy, Petrology, and Geochemistry. Ed. by E.S. Grew, de Gruyter. University of Maine. Burt, D.M. (1988). Stability of genthelvite, $\mathrm{Zn}_{4}\left(\mathrm{BeSiO}_{4}\right)_{3} \mathrm{~S}$ : an exercise in chalcophilicity using exchange operators. American Mineralogist, 73, 1384-1394.

Dubyna, A.V., Kryvdik, S. G., Sharygin, V.V. (2014). Geochemistry of alkali and nepheline syenites of the Ukrainian Shield: ICP-MS Data. Geochemistry International, 842-856. https://doi.org/10.1134/S0016702914080023

Dunn, P.J. (1976). Genthelvite and the helvine group. Mineralogical Magazine, 40, 627-636.

$\mathrm{Hsu}$, L.C. (1983). Some phase relationships in the system $\mathrm{BeO}-\mathrm{Al}_{2} \mathrm{O}_{3}$ $\mathrm{SiO}_{2}-\mathrm{H}_{2} \mathrm{O}$ with comments on effects of HF. Memoir of the Geological Society of China, 5, 33-46.

Miller, R.R. (1996) Structural and textural evolution of the Strange Lake peralkaline rare-element (NYF) granitic pegmatite, Quebec-Labrador. Canadian Mineralogist, 34, 349-371.

Whalen, J.B., Currie, K.L., Chappell, B.W. (1987). A-type granites: geochemical characteristics, discrimination and petrogenesis. Contributions to Mineralogy and Petrology, 95, 407-419.

Wood, S.A. (1992). Theoretical prediction of speciation and solubility of beryllium in hydrothermal solution to $300^{\circ} \mathrm{C}$ at saturated varpor pressure: application to bertrandite/phenakite deposits. Ore Geology Reviews, 7, 249-278.

Salvi, S., Williams-Jones, A.E. (1996). The role of hydrothermal processes in concentrating high-field strength elements in the Strange Lake peralkaline complex, northeastern Canada. Geochimica et Cosmochimica Acta, 60 1917-1932.

\section{Reference}

Bezpal'ko, N.A (1970). Petrology and accessory minerals of granites and metasomatites of Northern Volhynia. Kyiv: Naukova dumka. [in Ukrainian]

Buchinskaya, K.M., Nechaev, S.V. (1994). Tantalum-niobium mineralization of the Perzhansky ore cluster (Ukrainian shield). Mineralogical journal, 1, 15-29. [in Russian]

Galetskiy, L.S. (1966). The unusual paragenesis of gentelvine and cassiterite. Mineralogical digest of Lviv University, 20, 46-52. [in Russian]

Ginzburg, A.I., Zabolotnaya, N.P., Kupriyanova, I.I., Novikova, M.I., Shackaya, V.T., Shpanov, E.P., Shuriga, T.N., Getmanskaya, T.I. (1975). Genetic types of beryllium hydrothermal deposits. Moscow: Nedra. [in Russian]

Ginzburg, A.I., Zabolotnaya, N.P., Kupriyanova, I.I., Novikova, M.I., Shackaya, V.T., Shpanov, E.P. (1977). Regularity of beryllium hydrothermal deposits formation. Moscow: Nedra. [in Russian]

Gurvich, S.I., Zubko, L.B., Galetskiy, L.S. (1963). Gengelvine from silicified syenites. Report ASUSSR, 5, 1123-1124. [in Russian]

Dubyna, O.V., Kryvdik, S.G. (2014). Geochemical and petrological features of the alkaline granites of the Ukrainian Shield. Geological journal, 3 , 83-94. https://doi.org/10.30836/igs.1025-6814.2014.3.138807 [in Ukrainian]

Dubyna, A.V., Kryvdik, S. G., Sharygin, V.V. (2014). Geochemistry of alkali and nepheline syenites of the Ukrainian Shield: ICP-MS Data. Geochemistry International, 842-856. https://doi.org/10.1134/S0016702914080023

Esypchuk, K.E., Orsa, V.I., Sherbakov, I.B. et al. (1993). Granitoids of the Ukrainian shield. Petrochemistry, geochemistry, ore potential. Kyiv: Naukova dumka. [in Ukrainian]

Kogarko, L.N. (1977). Problem of agpaitic magma genesis. Moscow: Nauka. [in Russian]

Mehnert, K.R. (1971). Migmatites and the origin of granitic rocks. Moscow: Mir. [in Russian]

Metalydy, S.V., Nechaev, S.V. (1983). Sushchano-Perga region (geology, mineralogy, ore potential). Kyiv: Naukova dumka. [in Russian]

Myckevych, B.F., Bezpal'ko, N.A., Egorov, O.S. et al. (1986). Rare elements of the Ukrainian Shield. Kyiv: Naukova dumka. [in Russian]

Remeshylo, B.G., Vynar, O.N., Druchok, L.P., Samoylovych, L.G., Slysh, R.A. (1977). Conditions of zonal crystals of genthelviteformation. Abstract in "Mineralogical criteria for rare metals prospecting in the Ukrainian shield". Kyiv: Naukova dumka. [in Russian]

Hodakovskiy, I.L. (1975). Research of the aqueous solutions thermodynamics at high temperatures and pressures. Extended abstract ... Doctor's thesis. Moscow. [in Russian] 
Sharygin, V.V., Krivdik, S.G., Pospelova, L.N., Dubina, A.V. (2009). ZnKupletskite and Hendricksite in the Agpaitic Phonolites of the Oktyabrskil Massif, Azov Region, Ukraine. Doklady Earth Sciences, 3, 499-504. https://doi: 10.1134/S1028334X09030349 [in Russian]

Barton, M.D., Young, S. (2002). Non-pegmatitic Deposits of Beryllium: Mineralogy, Geology, Phase Equilibria and Origin. In Beryllium: Mineralogy, Petrology, and Geochemistry. Ed. by E.S. Grew, de Gruyter. University of Maine. http://doi: 10.2138/rmg.2202.50.01

Burt, D.M. (1988). Stability of genthelvite, $\mathrm{Zn}_{4}\left(\mathrm{BeSiO}_{4}\right)_{3} \mathrm{~S}$ : an exercise in chalcophilicity using exchange operators. American Mineralogist, 73,1384-1394.

Dunn, P.J. (1976). Genthelvite and the helvine group. Mineralogical Magazine, 40, 627-636.

$\mathrm{Hsu}$, L.C. (1983). Some phase relationships in the system $\mathrm{BeO}-\mathrm{Al}_{2} \mathrm{O}_{3}$ $\mathrm{SiO}_{2}-\mathrm{H}_{2} \mathrm{O}$ with comments on effects of HF. Memoir of the Geological Society of China, 5, 33-46.
Miller, R.R. (1996) Structural and textural evolution of the Strange Lake peralkaline rare-element (NYF) granitic pegmatite, Quebec-Labrador. Canadian Mineralogist, 34, 349-371.

Whalen, J.B., Currie, K.L., and Chappell, B.W., 1987, A-type granites: geochemical characteristics, discrimination and petrogenesis. Contributions to Mineralogy and Petrology, 95, 407-419.

Wood, S.A. (1992). Theoretical prediction of speciation and solubility of beryllium in hydrothermal solution to $300^{\circ} \mathrm{C}$ at saturated varpor pressure: application to bertrandite/phenakite deposits. Ore Geology Reviews, 7, 249278. https://doi.org/10.1016/0169-1368(92)90012-A

Salvi, S., Williams-Jones, A.E. (1996). The role of hydrothermal processes in concentrating high-field strength elements in the Strange Lake peralkaline complex, northeastern Canada. Geochimica et Cosmochimica Acta, 60, 1917-1932. https://doi.org/10.1016/0016-7037(96)00071-3

Надійшла до редколегії 15.12.19

О. Дубина ${ }^{1,2}$, д-р геол. наук, старш. наук. співроб.,

E-mail: dubyna_a@ukr.net;

С. Кривдік², д-р геол.-мінералог. наук, проф.,

E-mail: kryvdik@ukr.net;

В. Бельський ${ }^{2}$ канд. геол. наук,

E-mail: belskyi_vm@ukr.net;

О. Вишневськийㄹ, канд. геол.-мінералог. наук, старш. наук. співроб.

E-mail: vyshnevskyy@i.ua;

${ }^{1}$ Київський національний університет імені Тараса Шевченка,

ННI "Інститут геології", вул. Васильківська, 90, м. Київ, 03022, Україна;

${ }^{2}$ Інститут геохімії, мінералогії та рудоутворення ім. М.П. Семененка НАН України,

пр. Акад. Палладіна, 34, м. Київ, 03680, Україна

\section{ОСОБЛИВОСТІ БЕРИЛІЄВОЇ ТА РІДКІСНОМЕТАЛЕВОЇ МІНЕРАЛІЗАЦІЇ В СІЄНІТІ ПЕРЖАНСЬКОГО РОДОВИЩА (УКРАЇНСЬКИЙ ЩИТ)}

Наведено результати дослідження рудних та акцесорних мінералів із сієніту Пержанського родовища берилію. Серед Ве-вмісних мінералів діагностовано фенакіт і гентгельвін. Останній вирізняється максимальним, порівняно з опублікованими в літературі аналізами гентегьвіну Пержанського родовища, і близьким до максимального теоретичного вмістом ZnO, що зумовлено лужним характером досліджуваної породи ((Na+K)/Al=1,09). Гентгельвін є більш пізнім мінералом відносно фенакіту або утворюється за рахунок його заміщення в результаті підвищення лужності розплаву в процесі диференціації. 3 інших мінералів рідкісних металів виявлено колумбіт з підвищеним вмістом Mn, Y-силікат (кейвіїт-(Y)?), рідкісноземельний фторкарбонат (бастнезит). Наявність флюориту та рідкісноземельних карбонатів, агрегати яких часто приурочені до гентеельвіну або фенакіту, може свідчити, що в рудоносних флюїдах Ве і REE переносилися у вигляді комплексних фтор-карбонатних сполук. Ураховуючи геохімічні характеристики порід (метаглиноземисті, сублужного і лужного ряду, глибокі негативні Еu-аномалії, низький вміст Sr, Ba, підвищений - HFS елементів) Сущано-Пержанського району, причини збагачення на рідкісні метали і Ве пов'язані з інтенсивним польовошпатовим фракціонуванням вихідних розплавів, що зумовлювало пересичення лугами, збагачення леткими компонентами і рідкісними металамu (Be, Li, REE, Y, Nb, Ta) залишкових порцій магматичних розплавів гранітоїдного або сієнітового складу. Постмагматичні лужні розчини, збагачені $\mathrm{F} \mathrm{i} \mathrm{CO}{ }_{3}^{2-}$, сприяли концентруванню Ве у флюїдній фазі з подальшою його міграцією і кристалізацією генгельвіну.

Ключові слова: генгельвін, фенакіт, сублужні граніти, лужні сієніти, колумбіт, Пержанське родовище, Український щит.

А.Дубина ${ }^{1,2}$, д-р геол. наук, ст. науч. сотр.,

E-mail: dubyna_a@ukr.net;

С. Кривдик ${ }^{2}$ д-р геол.-минералог. наук, проф.,

E-mail: kryvdik@ukr.net;

В. Бельскийㄹ, канд. геол. наук,

E-mail: belskyi_vm@ukr.net;

А. Вишневский ${ }^{2}$ канд. геол.-минералог. наук, ст. науч. сотр.,

E-mail: vyshnevskyy@i.ua;

${ }^{1}$ Киевский национальный университет имени Тараса Шевченко,

УНИ "Институт геологии", ул. Васильковская, 90, г. Киев, 03022, Украина;

'Институт геохимии, минералогии и рудообразования им. Н.П. Семененко НАН Украины,

пр. Акад. Палладина, 34, г. Киев, 03680, Украина

\section{ОСОБЕННОСТИ БЕРИЛЛИЕВОЙ И РЕДКОМЕТАЛЛИЧЕСКОЙ МИНЕРАЛИЗАЦИИ В СИЕНИТЕ ПЕРЖАНСКОГО МЕСТОРОЖДЕНИЯ (УКРАИНСКИЙ ЩИТ)}

Приведены результаты исследования рудных и акцессорных минералов из сиенита Пержанской месторождения бериллия. Среди Ве-содержащих минералов диагностирован фенакит и гентгельвин. Последний отличается максимальным, по сравнению с опубликованным в литературе, анализами гентгельвина Пержанского месторождения, и близким к максимальному теоретическому содержанием $\mathrm{ZnO}$, что обусловлено щелочным характером исследуемой породы ((Na+K)/Al=1,09). Гентгельвин более поздний минерал относительно феенакита или образуется за счет его замещения в результате повышения щелочности расплава в процессе его дифференциации. Из других минералов редких металлов обнаружен колумбит с повышенным содержанием Мn, Y-силикат (кейвиит-(Y)?), редкоземельный фторкарбонат (бастнезит). Наличие флюорита и редкоземельных карбонатов, агрегаты которых часто приурочены к гентгельвину или фенакиту, может свидетельствовать о том, что в рудоносных флюидах Ве и REE переносились в виде комплексных фтор-карбонатных соединений. Учитывая геохимические характеристики гранитов и сиенитов (метаглиноземистые, субщелочного и щелочного ряда, глубокие негативные Еu-аномалии, низкое содержание Sr, Ва, повышенное - HFS элементов) Сущано-Пержанского района, причинь обогащения этих пород на редкие металлы (REE, Y, Nb, Ta) и Ве связанны с интенсивным полевошпатовым фракционированием исходных расплавов, что вызывало пресыщение щелочами, обогащение летучими компонентами и редкими металлами остаточных порций магматических расплавов гранитоидного или сиенитового состава. Постмагматические щелочные растворы, обогащенные $\mathrm{F}$ и $\mathrm{CO}{ }_{3}^{2-}$, способствовали концентрированию Ве во флюидной фазе с последующей его миграцией и кристаллизацией генгельвина.

Ключевые слова: генгельвин, фенакит, субщелочные граниты, щелочные сиениты, колумбит, Пержанское месторождение, Украинский щит. 